
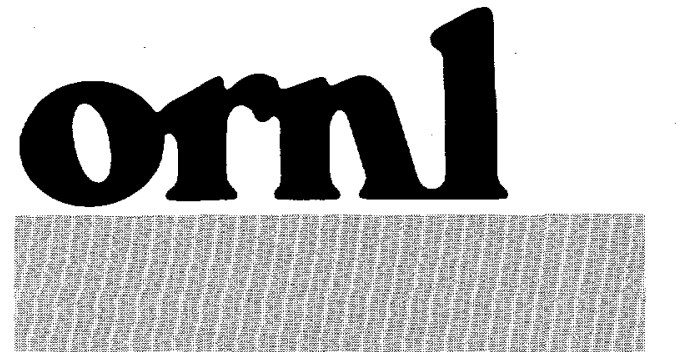

OAK RIDGE NATIONAL LABORATORY

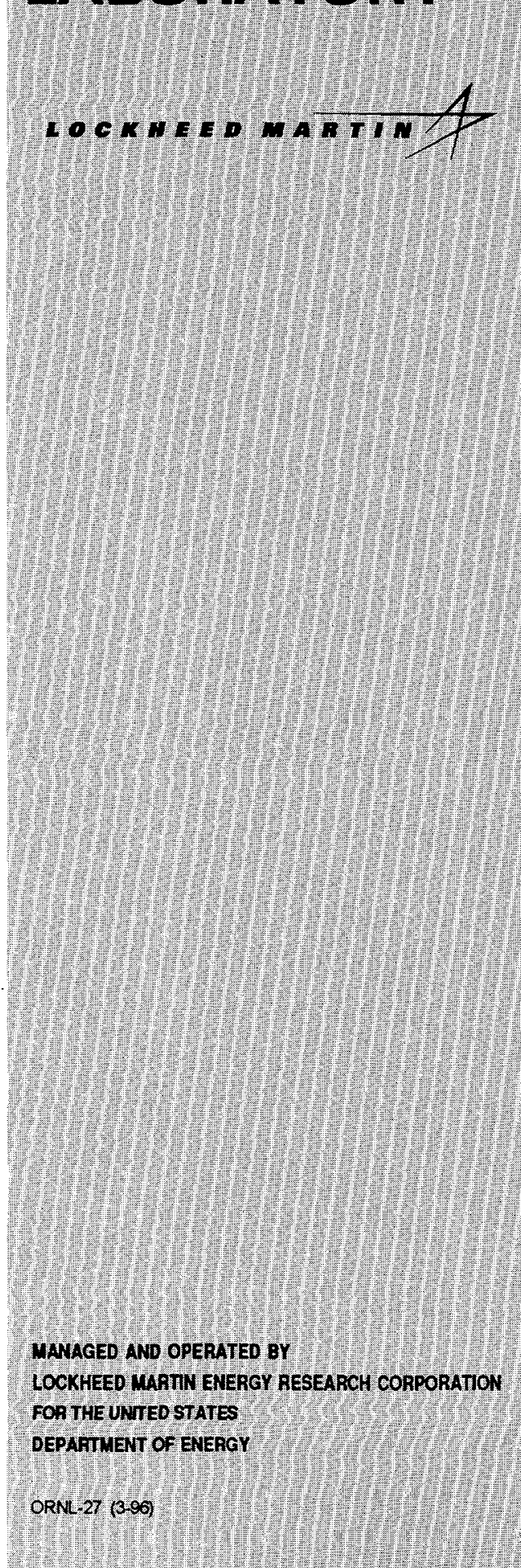

Energy Division

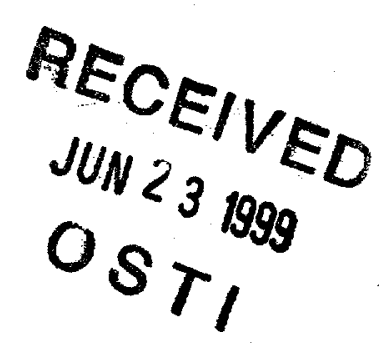

\section{Environmental Decision Making and Information Technology: Issues Assessment}

Bruce Tonn

Robert Turner

Jerry Mechling ${ }^{\dagger}$

Thomas Fletcher ${ }^{\dagger}$

Scott Barg ${ }^{\dagger}$

${ }^{7}$ Harvard University 



\section{DISCLAIMER}

This report was prepared as an account of work sponsored by an agency of the United States Government. Neither the United States Government nor any agency thereof, nor any of their employees, make any warranty, express or implied, or assumes any legal liability or responsibility for the accuracy, completeness, or usefulness of any information, apparatus, product, or process disclosed, or represents that its use would not infringe privately owned rights. Reference herein to any specific commercial product, process, or service by trade name, trademark, manufacturer, or otherwise does not necessarily constitute or imply its endorsement, recommendation, or favoring by the United States Government or any agency thereof. The views and opinions of authors expressed herein do not necessarily state or reflect those of the United States Government or any agency thereof. 


\section{DISCLAIMER}

Portions of this document may be illegible in electronic image products. Images are produced from the best available original document. 
ORNL/NCEDR-9

\title{
ENVIRONMENTAL DECISION MAKING AND INFORMATION TECHNOLOGY: ISSUES ASSESSMENT
}

\author{
Bruce Tonn \\ Robert Turner \\ Oak Ridge National Laboratory \\ Jerry Mechling \\ Thomas Fletcher \\ Scot Barg \\ Harvard University
}

May 1999

Prepared by the

OAK RIDGE NATIONAL LABORATORY

Oak Ridge, Tennessee 37831

managed by

LOCKHEED MARTIN ENERGY RESEARCH CORPORATION

for the

U.S. DEPARTMENT OF ENERGY

under contract DE-AC05-96OR22464 
This sub mitted in thuschipt has been authoted by t contractor of heUS G O y eronent under contractNo DE 1 C05 $960 R 22464$ Accoldingly.

The US Government retains a nonexclusive

royalty free licenseto publis 10 or ep roduce the pubits hed rom or this contibution, or allow others to do so 10 U US Government purposes. 


\section{TABLE OF CONTENTS}

EXECUTIVE SUMMARY

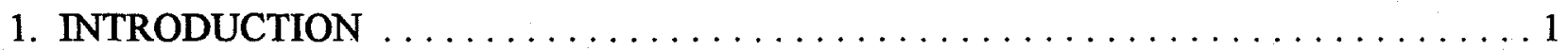

2. POTPOURRI OF ENVIRONMENTAL SYSTEMS $\ldots \ldots \ldots \ldots \ldots \ldots \ldots \ldots \ldots$

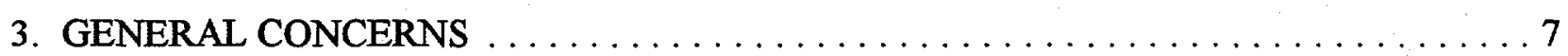

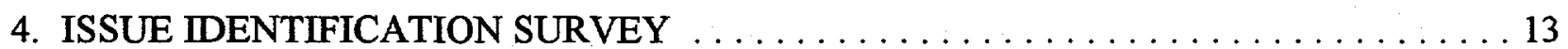

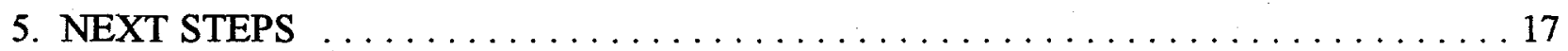

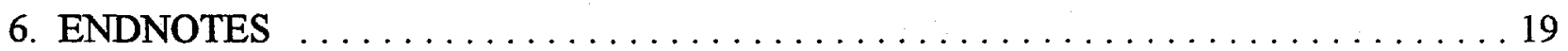

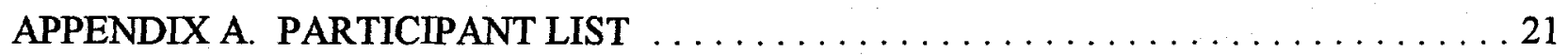

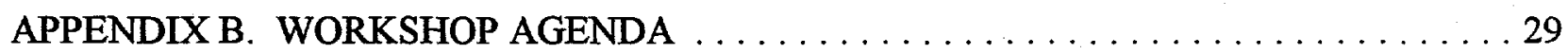





\section{EXECUTIVE SUMMARY}

This report presents a summary of the Information Technology and Environmental Decision Making Workshop that was held at Harvard University, October 1-3, 1998. Over sixty participants from across the United States took part in discussions that focused on the current practice of using information technology to support environmental decision making and on future considerations of information technology development, information policies, and data quality issues in this area. Current practice is focusing on geographic information systems and visualization tools, Internet applications, and data warehousing. In addition, numerous organizations are developing environmental enterprise systems to integrate environmental information resources. Plaguing these efforts are issues of data quality (and public trust), system design, and organizational change. In the future, much effort needs to focus on building community-based environmental decision-making systems and processes, which will be a challenge given that exactly what needs to be developed is largely unknown and that environmental decision making in this arena has been characterized by a high level of conflict.

Experimentation and evaluation are needed to contribute to efficient and effective learning about how best to use information technology to improve environmental decision making. 



\section{INTRODUCTION}

This report presents a summary of the Information Technology and Environmental Decision Making Workshop that was held at Harvard University, October 1-3, 1998. The workshop was hosted by the Strategic Computing and Telecommunications in the Public Sector Program of Harvard's Kennedy School of Government (KSG) ${ }^{1}$ and supported by the National Center for Environmental Decision-Making Research (NCEDR). ${ }^{2}$ The workshop drew over sixty attendees (Appendix A) from across the United States, representing state and local government, the federal government, the research community, and vendors and consultants. The purposes of the workshop were to assess the current practice of using information technology to support environmental decision making - what works and what does not work - and to explore future considerations of information technology development, information policies, and data quality issues. (The workshop agenda is contained in Appendix B.)

Information technology is transforming the practice of environmental protection, much as it is transforming virtually every other aspect of American life. The Internet and advanced database systems provide users access to environmental data anytime from anywhere. The Internet facilitates communication about environmental issues at many scales, such as within communities and regions and across the nation and the globe. Sophisticated decision support and visualization systems assist decision makers in structuring and evaluating environmental decisions. Enterprise systems are helping environmental protection organizations redesign their processes from static linear systems to more flexible, non-linear systems.

The challenges for information technology to improve environmental decision making are extreme because environmental decision making is a particularly demanding endeavor. For example, it is not enough to provide access to environmental data over the Internet; the data need to be accompanied by easily understood metadata and be of high quality. It is not enough to provide a system to allow people to communicate with each other better; the system needs to be accessible by all stakeholders within the community and region and possibly tailored to meet 
language and cultural needs. Decision support systems cannot focus on one or two decision variables; instead, in many instances, they must integrate numerous sources of emissions, complex atmospheric, ecological, and/or hydrological processes, complicated exposure pathways to humans and ecosystems, sophisticated dose-response models, and socioeconomic models to evaluate policies and complete the modeling loop.

Enterprise systems should not focus on modes of environmental protection of the 1970s but on modes for the 21st century. Original environmental protection efforts focused on reducing emissions from easily identified and major point sources through command and control efforts. Efforts now focus on reducing pollution from dispersed non-point sources, understanding the combined and cumulative impacts to human health and ecosystems from numerous pollutants, and encouraging compliance through collaborative programs rather than coercive regulations. Thus, information technology needs to support a much broader and complex environmental protection community. The entire endeavor is extremely daunting because all these areas of application for information technology interact and overlap and touch on the lives of virtually every citizen, firm, non-governmental organization, and government institution in the country.

The workshop participants made it very clear that much has already been accomplished in using information technology to improve environmental decision making but that much remains to be done. The first part of this report summarizes applications discussed by the participants. The second part presents several general concerns raised by participants during discussions of case studies, in break-out sessions, and in plenary sessions. The third section presents the results of an interactive survey taken during the workshop to identify those areas of information technology that need the most development and could offer the most benefits to the environmental decision making community. The report concludes with several recommendations for next steps. 


\section{POTPOURRI OF ENVIRONMENTAL SYSTEMS}

As is the practice at workshops organized by the Strategic Computing and Telecommunications in the Public Sector Program at KSG, several people were asked to share their experiences with systems they had developed or were developing. At this workshop, seven current practice sessions gave an overview of the state-of-the-art in the application of information technology to environmental decision making.

Two presentations focused on the growing use of geographical information systems (GIS) in this area. One presentation described how GIS is being used to assist the clean-up and redevelopment of six thousand brownfield sites in New York City. The GIS incorporates a broad set of data fields (e.g., zoning, land use, building type, ownership, assess valuation, and lot size), integrates several other data sources (e.g., the New York State registry of inactive hazardous waste disposal sites and Resource Conservation and Recovery Act and Comprehensive Environmental Response, Compensation, and Liability Information System \{CERCLIS\} data from US Environmental Protection Agency), and encompasses several overlays (e.g., empowerment, enterprise, and economic development zones, rail lines). It is clear that New York City is benefitting greatly from this GIS. The second presentation addressed the assessment of the general benefits of using GIS and how to determine how much money and time should be invested in GIS. This question requires a great deal more research primarily because many benefits to environmental decision making of GIS are non-monetary in nature and because investments are still needed to push user organizations, if not society, up the learning curve.

Two presentations focused on Internet database applications. One presentation described EPA's award-winning Envirofacts Data Warehouse, which integrates environmental data resources, detailed metadata describing the database, and public information about the environment. ${ }^{3}$ Envirofacts contains data from many EPA program system databases, including: CERCLIS, the Resource Conservation and Recovery Information System (RCRIS); the Toxic Release Inventory System; and the Safe Drinking Water Information System. Envirofacts also 
contains, through its EPA Spatial Data Library System, base geographic coverages for the United States, including political boundaries, roads, rivers, etc. The system is currently receiving more than one million hits per month from more than eighty countries around the world.

A second database application complements this first one. Supported by the Environmental Defense Fund (EDF), the Chemical Scorecard Project has developed an Internetaccessible database designed to supplement raw data from other sources with additional information needed to characterize the public health impacts of pollution. ${ }^{4}$ For example, the Scorecard is linked to Toxic Release Inventory data from EPA to translate into public health impacts the consequences of the chemicals released into a community by local industry. Every effort is made to interpret extensive amounts of complex environmental data into terms understandable by the general public.

Three presentations addressed the work that government organizations are doing to better use information technology to support environmental decision making. One presentation described the effort that the Washington State Department of Ecology is undertaking to integrate environmental information across departments and programs. A second presentation described the creation of a web-based record of New Jersey environmental data by the New Jersey Department of Environmental Protection, county and municipal governments, special interest groups, and academic departments, bureaus, centers, and institutes. A third presentation described the efforts of EPA's Office of Research and Development to implement a strategic plan to achieve an integrated system of scientific environmental information (e.g., to help users find relevant scientific data and information and appropriate models and tools). A common theme among these three efforts is the need to overcome organizational barriers that can thwart the development of pan-organizational data systems.

In combination, these presentations represent well the current use of information technology to support decision making (e.g., using GIS), to provide access to data, and to integrate organizational efforts. The presentations also highlighted many of the challenges in these 
areas. For example, how much should an organization spend on a GIS? What is the best way to communicate environmental information over the Internet? How much patience is needed to overcome institutional barriers to data and information (answer: much!)? The presentations also showed how information technology is changing the organizational environment in this area. GIS systems foster public involvement in brownfields remediation, thereby challenging typical bureaucratic-centered modes of decision making. The Internet has raised the profile of information providers and has the potential to create a more open culture within environmental protection enforcement agencies. Data and information integration efforts are forcing increased communication and cooperation within institutions and across institutions, thereby placing more importance on facilitation and collaboration than on traditional turf-building and defense. 



\section{GENERAL CONCERNS}

A review of workshop presentations and discussions reveals three central concerns that participants have about using information technology to improve environmental decision making: how to build flexible systems; how to handle data quality issues; and how to change organizational culture to make the best use of information system capabilities.

A very difficult problem concerns the flexibility and functionality of information systems. Though major advances have been made in recent years in software development, computing power, and telecommunications bandwidths, most substantial information systems are expensive and time-consuming to develop and possess limited capabilities. In many ways, major information systems resemble major capital investments - they are key investments that are hard to change in the short run. Thus, it is important for organizations to build information systems that provide the most contribution to achieving strategic goals.

Unfortunately, there are many examples of information systems whose inflexibility and limited functionality lead to widespread consternation and act as barriers to change. Two examples received extensive attention during the workshop. First, these issues were vividly illustrated in a case study written about the development of an information system to assist the Houston police department respond to incident calls. The system was designed to support a specific model of policing, one that emphasized quick response times of mobile units to crime scenes. When reformers in the department wished to implement a community policing model, one that emphasizes prevention and personal interaction of police officers with members of the community, they found that the in-place information system could not support this initiative. Plus, they learned that changing the present system would cost time and money, neither of which was available at that time. Thus, the limited capabilities of the information system greatly influenced policy within this police department. 
A second example that was extensively discussed was the Open Access Same-time Information System (OASIS) developed by the Federal Energy Regulatory Commission (FERC). OASIS was designed to support the deregulated electric power industry to manage access to transmission resources. In the regulated world, electric utilities owned not only their own transmission systems and distribution systems but also their own power generation plants. In the deregulated world, different organizations own generation plants, transmission systems, and distribution systems. To make the playing field level for those owners of generation facilities that need to deliver power to customers over transmission systems that are owned by others, the OASIS system sets up a system for power generators to bid for transmission capacity. Unfortunately, while in theory the bidding model is attractive, it does not mesh well with the physical realities of power transmission. In fact, the 'bids' requested by OASIS are numbers that have no basis in power systems engineering and do not facilitate sound management of the national power transmission grid. In fact, the system makes it more difficult to keep the system from crashing, thereby resulting in widespread power outages. Thus, this system, although recently developed, shackles progress toward this national policy goal.

In response to these examples and the general observation that many systems may be designed to do what is easy and not what is needed, discussion centered on a risk-based model to guide system development. This model adopts a life-cycle approach to system development, where the system alternatives are considered in their entirety from planning to evaluation, to provide system developers with the best insight possible about what needs to be done. This model has eight elements:

1. Risk identification - What are the major threats to the organization's being able to achieve its mission and strategic goals?

2. Risk assessment - What are the likelihoods of these risks and the consequences to the organization?

3. Prioritization - Which risks need to be addressed first, second, etc. ?

4. Definition - What can be done to reduce the threat of these risks? 
5. Disaggregation - What specific steps are needed to reduce the risks?

6. Resource allocation - How much time and money is needed to build the information systems and other processes to implement the steps?

7. Action planning - What actions must be taken today and tomorrow to implement the plan? and

8. Implement, monitor, and evaluate - What can be learned from this system development process?

It was argued that this process will help organizations look at the major risks to their organizations and squarely face those challenges. This model will also help organizations build strategic alliances to build and implement the systems.

Many participants expressed concerns over the quality of data that are being made or could be made accessible to the public. In addition, there were concerns about the quality of data available to support science and policy analysis. Problems associated with bad data extend far beyond flawed policy analysis. Indeed, many participants were more worried about the public's reactions to bad data. Specifically, participants worried about losing hard-won trust, especially if the public came to believe that their agencies purposely provided bad data to mislead the public, or if the public came to believe that environmental standards were being exceeded. They also worried that the public might not understand the limitations of the data and make decisions that the data might not support. The emphasis on data quality is understandable in retrospect, as most workshop participants were involved with developing and/or administering information systems to manage environmental data internally or to provide access to environmental data externally. Examples of the former include the scientific information integration effort at EPA and the information integration effort of the State of Washington. Examples of the latter include the Envirofacts effort of EPA and the Chemical Scorecard Project of the EDF.

The quality of data can be impinged upon in many ways. Data may be incomplete or lack coverage, both spatially and temporally. The validity of the data may be questionable (e.g., the 
measurements made to produce the data may lack precision and the magnitude and direction of the resulting errors may be unknown). Databases may not have enough of the right kinds of information to support specific policy analyses. Database documentation may be poor and the metadata weak and/or not understandable. The data may also be out-of-date. Any of these limitations or additional ones may not be well communicated to users.

Discussion on this topic ranged from black-and-white views (if the data are not good, do not make them available to anyone, because they are useless) to the view that it is important to make all data available as long as the quality is explicitly explained. How to explain data quality to the general public is an open research question, although much can be learned from graphical interface, consumer product design, and computer visualization research and the fields of risk communication and perception. With respect to the development of metadata, many participants follow the twenty-year rule where metadata descriptions should be sufficient to let somebody use the data twenty-years after the data were created. With respect to building trust in data, it was suggested that external validation of the data be conducted by neutral third parties.

Lastly, as hinted at in the previous section, it is difficult to change organizational cultures to combine with the strengths of information technology to produce superior man-machine systems for the betterment of environmental decision making. Organizational culture extends beyond the borders of any one department or agency. It also includes legislatures and the public. For example, at times the most difficult problem facing system developers is convincing legislatures (or other funding bodies) to allocate funds for new systems initiatives. In addition, as noted above, getting people to collaborate across organizational boundaries to produce environmental information systems that are more than the sum of the parts can be quite difficult. Complicating this task is the fact that environmental data can be quite complex, cover many media, and represent many different scales and times. Thus, fitting air and water and solid waste and other environmental data together is not always easily accomplished, irrespective of the political difficulties. 
Obviously, strong leadership is needed to overcome this problem. Of course, leaders need institutional support, which may prove to create a Catch-22 situation for many organizations. Leaders need to have patience and adopt a facilitative role to get everyone involved. Rapid prototyping of systems can help by allowing frequent comments on system development and frequent reassessment of the match between the system and the needs of all the relevant users. 



\section{ISSUE IDENTIFICATION SURVEY}

Another staple of the Strategic Computing and Telecommunications in the Public Sector Program is an interactive survey with workshop participants. In this case, participants were asked how involved their organizations were in each of 12 areas and how much each area has to contribute to the betterment of environmental decision making in the future. The 12 areas are:

1. Data Standards: Develop, disseminate, and enforce data (and metadata) standards as a fundamental component of environmental initiatives;

2. Environmental Results Data: In addition to collecting data on relevant economic and enforcement activities, prioritize the collection and dissemination of data to assess the environmental results of specific initiatives;

3. Electronic Data Gathering: Increase use of electronic data gathering and monitoring to improve collection efficiency and provide more "real-time" data;

4. Data Warehousing: Maximize the benefits of data that have already been collected by creating and maintaining data warehouses and/or libraries to allow one-stop access to environmental data;

5. GIS and Visualization Tools: Make accurate, timely, and rich geographic data and visualization tools a foundation for environmental decision making by scientists, the public, and other stakeholders;

6. Decision Support Systems: Develop systems to support the iterative data examination and decision making required for complex problems with multiple variables (such as problems related to air quality management);

7. The Internet: Aggressively utilize the Internet and World Wide Web to provide an unprecedented degree of public and stakeholder access to complex environmentally relevant data;

8. Community-based Environmental Decision Making: Augment needed top-down analysis with the data and analysis needed to support environmental decision making where it matters most to people - in their own 'back yards;' 
9. Independent Environmental Monitoring: Because making environmental data useful requires an enormous amount of work, a clear focus on the measurement task, and freedom from undue external influence, create independent units for environmental monitoring;

10. Communication and Education: As an early and fundamental set of initiatives, develop better ways to communicate with and educate the public and other stakeholders on the availability and uses of environmental data and analysis;

11. Pricing to Cover Costs: To create incentives for organizations to share environmental and other data, develop pricing policies to allow agencies to equitably recover more of the costs of data collection and analysis; and

12. Global Analysis and Decision Making: While community-based environmental efforts are essential, local decision making must be informed and influenced by global analysis and decision processes.

The results of this survey are very interesting. Related to what is happening now with respect to environmental decision making and information technology, the most prominent activities are: GIS and visualization tools, the Internet, data warehousing, and data standards. The least prominent activities are: pricing to recover costs, independent environmental monitoring, global analysis and decision making, and decision support systems.

What activities can make the best future contributions to the betterment of environmental decision making are somewhat different from what is happening now. In order of importance, the top four activities in the opinion of the workshop participants are: the Internet, communication and education, community-based decision making, and GIS and visualization tools. Data warehousing and data standards receive much less support. Thus, these results express the view that the public needs to become more involved in environmental decision making at the community level and that tools such as the Internet and GIS can foster these goals. Education is important because in many instances the public may not have the wherewithal to bridge science and policy. Conversely, working more with the public will benefit environmental decision makers and system developers because often the public is ahead of these groups in understanding what environmental issues are important in their communities. 
The participants were also asked to rate how much confusion and conflict is associated with each of the 12 actions. Specifically, participants were asked "What degree of confusion or ambiguity is associated with each idea?" and "What degree of conflict is associated with each idea?" The motivation behind this question is that different modes of decision making are needed to promote actions that have different confusion and conflict scores. The model presented at the workshop is captured in Table 1 below.

Table 1: Relating Confusion and Conflict to Decision Modes.

\begin{tabular}{|l|l|l|}
\hline & Low Conflict & High Conflict \\
\hline High Confusion & Mode: Vision, Plans & Mode: Judgement, care \\
\hline Low Confusion & Mode: Action (Just do it!) & Mode: Clout, negotiation \\
\hline
\end{tabular}

In this model, Low Confusion and Low Conflict justifies an action-oriented, just-do-it mentality. It is clear what needs to be done and the best decision strategy is agreed upon. If the goal is clear but there is conflict about means, then maybe political clout or the implementation of conflict management processes is justified. On the other hand, if the people are confused about what to do but share a common purpose, then vision is needed and people need to discuss alternative plans until the confusion is reduced. High Conflict and High Confusion situations are most trying and require judgement and care to get through.

Three of the top four actions rated by workshop participants as having high future contributions fell into the Low Confusion - Low Conflict category: the Internet, communication and education, and GIS and visualization tools. With respect to the Internet and tools, workshop participants stated that they need to keep at these actions of which they have gained an understanding, and which most people agree are well worth doing. Communication and education need to be done more, but how to go about these activities is well known and most people agree on their benefits. 
The fourth top action fell into the High Confusion - High Conflict category and that is community-based decision making. The country is in the midst of a renewed focus on communitybased environmental decision making. Much is to be learned about how to accomplish this. What has been experienced is a great deal of conflict and much frustration. There is often a clash of value systems (e.g., economic versus environmentalist). The sheer number of stakeholders involved can cause problems with the logistics of environmental decision making processes. This list could go on. However, a strong focus on this challenging action with the support of three more understood and implementable actions will help in improving community-based decision making. 


\section{NEXT STEPS}

In summary, much has been accomplished in the way of using information technology to support environmental decision making. The explosive growth of environmentally-related websites in the past several years, the development of comprehensive environmental databases, and the creation of sophisticated computer-based tools such as GIS support this conclusion.

As mentioned above, one focus for near- and mid-term efforts is at the community level. Efforts to move environmental decision making and policy responsibilities from the federal (and state level) down to the community level make this a necessity. Also, communities across the country are accepting this responsibility and looking beyond compliance to create sustainable communities. That many communities do not have the financial and technical resources to make full use of available information technologies allows a role for federal and state agencies, nongovernmental organizations, and local educational institutions.

Numerous issues were discussed in relation to this goal. For example, every effort needs to be made to make community-based systems accessible to everyone in the community. This means working with libraries, schools, and other community-based organizations to provide access to technology. Leadership was also mentioned as an important issue. Tying leadership to different modes of decision making to information system design provides an integrated means for solving this problem. Involving as many people through participative design processes to build their systems is also important.

It was noted on several occasions that widespread integration of advanced information systems may set the stage for changing the relationships among the major institutions in society: government, the private sector, and the life institutions (e.g., family, community). Foresight is needed to anticipate these potential changes, along with potential enhancements to information technologies. The technology itself could be used to help manage change in institutional relationships. 
Numerous more narrowly defined research activities need to be pursued to support this entire endeavor. For example, as mentioned above, the whole issue of how to describe and communicate data quality is very important. Additionally, how to describe and communicate uncertainties related to future scenarios and policy choices supported by data and models producing results based on data is a second important research area. User interface design, cultural reactions to community-based systems, and environmental education are other critical research areas.

Lastly, experimentation and evaluation are essential to advance the art of using information technology to support information decision making. Use of the Internet to widely distribute environmental information is in its beginning stages. Many different approaches are being tested. These need to be thoroughly evaluated. It is not known how best to design community-based information systems to support environmental decision making (or any other community needs, for that matter). Communities need support to build systems and to experiment with different designs, and researchers need to evaluate these systems. Several workshop participants stressed that they hoped that restrictive Internet pricing policies would not become a significant barrier to moving up the information technology - environmental decision making learning curve.

In conclusion, information technology can be leveraged to improve environmental decision making. The biggest opportunity at this point is to continue to develop Internet resources. This is straightforward technically and not very controversial politically. However, simultaneous with these efforts, much progress needs to be made to improve the quality of data made accessible by the Internet, the ways of communicating data quality and use values, and the education of the public in how to best understand and use environmental data. All these efforts need to focus, in part, on community-based environmental decision making. 


\section{ENDNOTES}

1. For more information on the Strategic Computing and Telecommunications in the Public Sector Program, please visit http://www.ksg.harvard.edu/stratcom.

2. NCEDR has three member organizations, Oak Ridge National Laboratory, the University of Tennessee-Knoxville, and the Tennessee Valley Authority. NCEDR was founded through a grant from the National Science Foundation. For more information on NCEDR, please visit http://www.ncedr.org/.

3. Envirofacts Data Warehouse can be found at http://www.epa.gov/enviro/.

4. The Chemical Scorecard can be found at http://www.scorecard.org/. 

APPENDIX A. PARTICIPANT LIST

\section{INFORMATION TECHNOLOGY AND ENVIRONMENTAL DECISIONMAKING \\ Participant List}

October 1-3, 1998

Mr. Lee Dillard Adams

Deputy Director

Department of Environmental Protection

Commonwealth of Massachusetts

627 Main Street

Worcester, MA 01608

508-767-2775

lee.adams@state.ma.us

Mr. Roland V. Anglin

Deputy Director

Community Resource Development

Ford Foundation

320 East 43rd Street

New York, NY 10017

212-573-4646

r.anglin@fordfound.org

Ms. Annette Barbaccia

Director

Office of Environmental Coordination

City of New York

One Centre Street, Room 2358

New York, NY 10007

212-788-2937
Ms. Barbara Allan

Division Director

Planning \& Evaluation

Department of Environmental Protection

Commonwealth of Massachusetts

One Winter Street

Boston, MA 02108

617-292-5593

barbara.kuetz@state.ma.us

Mr. Russell D. Baier

Director

Policy Research Division

State of Texas

P.O. Box 13087, MC206

Austin, TX 78711-3087

512-239-1483

rbaier@tnrcc.state.tx.us

Mr. Scot N. Barg

Research Affliate

Strategic Computing and Telecommunications

The John F. Kennedy School of Government

Harvard University

79 John F. Kennedy Street

Cambridge, MA 02138

617-495-6206

scot_barg@harvard.edu 
Dr. Pamela M. Berger

Director of Environmental Policy

Mayor's Office

City of Houston, TX

901 Bagby - 4th Floor, City Hall

Houston, TX 77002

713-437-6168

pberger@myr.ci.houston.tx.us

Mr. Michael W. Christensen

U.S. Environmental Protection Agency

6515 Lakeview Drive

Falls Church, VA 22041

703-750-2417

Ms. Wendy Cleland-Hamnett

Acting Director

Office of Policy, MC2131

U.S. Environmental Protection Agency

401 M Street, S.W.

Washington, DC 20460

202-260-4030

cleland-hamnett.wendy@epamail.epa.gov

Mr. James C. Colman

Assistant Commissioner

Bureau of Waste Prevention

Department of Environmental Protection

Commonwealth of Massachusetts

One Winter Street

Boston, MA 02108

617-292-5549

james.colman@state.ma.us

Mr. Gordon S. Creed

Deputy Assistant Commissioner

U.S. General Services Administration

$1800 \mathrm{~F}$ Street, NW

Washington, DC 20405

202-501-0084

gordon.creed@gsa.gov
Mr. Jeffrey W. Byron

Director of Information Technology

One Stop Program

U.S. Environmental Protection Agency

401 M. Street, S.W.

Washington, DC 20460

202-260-0495

byron.jeff@epa.gov

Mr. William C. Clark

Harvey Brooks Professor

International Science, Public Policy \& Human Development

The John F. Kennedy School of Government

Harvard University

79 John F. Kennedy Street

Cambridge, MA 02138

617-495-3981

william_clark@harvard.edu

Mr. Matthew Cogliano

Chief of Boston Water and Sewage Commission

MIS Section

Department of Environmental Protection

Commonwealth of Massachusetts

One Winter Street

Boston, MA 02108

617-625-7906

matthew.cogliano@state.ma.us

Mr. Henry Colon

Deputy Director

Office of Environmental Coordination

City of New York, NY

One Centre Street, Room 2358

New York, NY 10007

212-788-2928

Mr. George Crombie

Undersecretary

Executive Office of Environmental Affairs

Commonwealth of Massachusetts

100 Cambridge Street

Suite 2000

Boston, MA 02202

617-727-9800 
Ms. Mary Margaret Cronin

Director

Disability Determination Services Redesign \&

Organizational Analysis

State of New York

P.O. Box 165

Albany, NY 12260

518-473-0070

Mr. Glen Daraskevich

Environmental Engineer III

Department of Environmental Protection

Commonwealth of Massachusetts

One Winter Street

Boston Water and Sewage Commission - 7th Floor

Boston, MA 02108

617-556-1151

glen.daraskevich@state.ma.us

Mr. David A. Delorenzo

Deputy Regional Director

Department of Environmental Protection

BRP - SERO

Commonwealth of Massachusetts

20 Riverside Drive

Lakeville, MA 02346

508-946-2704

Ms. Aisling Eglington

Environmental Analyst

Bureau of Waste Prevention

Department of Environmental Protection

Commonwealth of Massachusetts

One Winter Street

Boston, MA 02108

617-348-4001

aisling.eglington@ma.us

Mr. Mike Field

Data Management Supervisor

Department of Environmental Quality

State of Montana

2209 Phoenix Avenue

Helena, MT 59601

406-444-5330

mfield@mt.gov
Mr. David Damm-Luhr

Chief of Change Management

U.S. Department of Transportation Volpe Center

U.S. Department of Transportation

55 Broadway Street

Cambridge, MA 02142

617-494-2102

dammluhr@volpe1.dot.gov

Ms. Martina B. Delaney

Environmental Analyst III

Department of Environmental Protection

State of Connecticut

79 Elm Street

3rd Floor

Hartford, CT 06106

860-424-3579

tina.delaney@po.state.ct.us

Mr. Adel Ebeid

Chief Information Officer

Department of Environmental Protection

State of New Jersey

401 East State Street

P.O. Box 428

Trenton, NJ 08625

609-292-3211

aebeid@dep.state.nj.us

Mr. Fred Ellerbusch

Senior Research Fellow

National Environmental Policy Institute

P.O. Box 4225

Warren, NJ

732-563-4944

fred@systemsthink.com

Mr. Thomas M. Fletcher

Associate Director

Strategic Computing and Telecommunications

John F. Kennedy School of Government

Harvard University

79 JFK Street

Cambridge, MA 02138

617-964-7118

thomas_fletcher@harvard.edu 
Mr. Jeffrey B. Frithsen

Information Management Specialist

National Center for Environmental Assessment

U.S. Environmental Protection Agency

401 M. Street, SW (8601-D)

Washington, DC 20460

202-564-3323

frithsen.jeff@epa.gov

Mr. Howard G. Graeffe

Executive Director

National Institute for Environmental Renewal

1300 Old Plank Road

Mayfield, PA 18433

717-282-0302

hgg@nier.org

Dr. William W. Hogan

Bradshaw Professor of Public Policy and Management

John F. Kennedy School of Government

Harvard University

79 JFK Street

Cambridge, MA 02138

617-495-1317

Mr. Ronald Jantz

Social Sciences Data Librarian

Alexander Library

Rutgers University

169 College Avenue

New Brunswick, NJ 08901

732-932-8573

rjantz@rci.rutgers.edu
Mr. Louis F. Gitto

Special Assistant to the Deputy Commissioner Department of Environmental Protection Commonwealth of Massachusetts

One Winter Street

Boston, MA 02108

617-556-1192

lou.gitto@state.ma.us

Mr. Philip Griffiths

Director

GIS Program

Department of Environmental Protection

Commonwealth of Massachusetts

One Winter Street

Boston, MA 02108

617-292-5675

pgriffiths@state.ma.us

Ms. Charmaine Iversen

Program Manager

U.S. Environmental Protection Agency

$220 \mathrm{C}$ Street, NW

Washington, DC 20520

202-647-1003

iversencm@state.gov

Mr. Paul D. Joseph

Operations Manager

Xerox Corporation

7900 Westpark Drive

McLean, VA 22102

703-790-3727

paul_joseph@co.xerox.com

Ms. Rosanne Kruzich

President

RKX Consulting

750 Zorn Avenue, \#56

Louisville, KY 40206

502-895-4559

rkruzich@bellsouth.net 
Ms. Linda Langschied

Information Services Librarian

Alexander Library

Rutgers University

169 College Avenue

New Brunswick, NJ 08903

732-932-7129

langschi@rci.rutgers.edu

Dr. Charles D. Linville

Assistant Professor

Computer Science and Information Systems

American University

4400 Massachusetts Avenue, NW

Washington, DC 20016

202-885-3138

clinville@worldnet.att.net

Mr. Michael MacDougall

Manager

U.S. Environmental Protection Agency

JFK Federal Building

Boston, MA 02203

617-565-3377

macdougall.mike@epamail.epa.gov

Ms. Charlene McMahon

Economic/Business Analyst

The Mitre Corporation

202 Burlington Road, MS S107

Bedford, MA 01730

781-271-6239

cmcmahon@mitre.org

Ms. Shelley Metzenbaum

Director

Performance Management Project

The John F. Kennedy School of Government

Harvard University

79 John F. Kennedy Street

Cambridge, MA 02138
Mr. Stanley L. Laskowski

Director

Environmental Services Division

U.S. Environmental Protection Agency

1615 Art Street

Philadelphia, PA 19107

215-814-2989

laskowski.stanley@epamail.epa.gov

Ms. Marianne L. MacDonald

Systems Analyst

Department of Environmental Protection

Commonwealth of Massachusetts

One Winter Street

Boston, MA 02108

617-292-5670

marianne.macdonald@state.ma.us

Mr. John Q. Martin

Realty Officer

GSA/Public Buildings Service

U.S. Property Disposal Center of Expertise

1800 F Street, NW, Room 4224

Washington, DC 20405

202-501-4671

john.martin@gsa.gov

Dr. Jerry Mechling

Director

Strategic Computing and Telecommunications

John F. Kennedy School of Government

Harvard University

79 JFK Street

Cambridge, MA 02138

617-495-3036

jerry_mechling@harvard.edu

Mr. Lawrence O'Connor

Booz, Allen \& Hamilton

8283 Greensboro Drive

McLean, VA 22102

703-917-2078

oconnorlaw@bah.com 
Mr. Thomas Parris

Environmental Resources Librarian

Harvard University

Lamont Library

Cambridge, MA 02138

617-496-6158

tparris@fas.harvard.edu

Ms. Suzi Peck

Info 2001 Project Manager

Info 2001

Department of Environmental Protection

Commonwealth of Massachusetts

One Winter Street

Boston, MA 02108

617-292-5870

susan.peck@state.ma.us

Ms. Deborah A. Quinn

Chief Information Officer

Information Technology Office

Department of Environmental Protection

Commonwealth of Massachusetts

One Winter Street

Boston, MA 02108

617-292-5911

deborah.quinn@state.ma.us

Mr. Bruce Seigle

Chief Information Officer

Metropolitan Sewer District

City of Louisville, $\mathrm{KY}$

700 West Liberty Street

Louisville, KY 40203

502-540-6234

seigle@lojic.org

\section{Mr. Glenn Shankle}

Deputy Executive Director

Natural Resources Conservation Commission

State of Texas

12100 Park 35 Circle

Austin, TX 78753

512-239-3900

gshankle@tnrcc.state.tx.us
Dr. William S. Pease

Senior Scientist

U.S. Environmental Defense Fund

5655 College Avenue

Oakland, CA 94618

510-658-8008

billp@edf.org

Mr. Peter Preuss

Office Director

U.S. Environmental Protection Agency

$401 \mathrm{M}$. Street, SW

Washington, DC 20460

202-564-6825

preuss.peter@epamail.epa.gov

Ms. Mercedes Sahagun

Assistant Commissioner

Department of Environment

City of Chicago, IL

30 North La Salle

Suite 2500

Chicago, IL 60602

512-744-9136

msahagun@ci.chi.il.us

- Mr. Edward Serna

Deputy Director of Administrative Services

Natural Resources Conservation Commission

State of Texas

Austin, TX 78753

512-239-0590

eserna@tnrcc.state.tx.us

Mr. Lynn Singleton

Information Integration Manager

Department of Ecology

State of Washington

P.O. Box 47600

Olympia, WA 98504

360-407-6610

lsin461@ecy.wa.gov 
Dr. Malcolm K. Sparrow

Lecturer in Public Policy

John F. Kennedy School of Government

Harvard University

79 JFK Street

Cambridge, MA 02138

617-495-8359

malcolm_sparrow@harvard.edu

Ms. Richelle Tolton

Graduate Research Assistant

Earth Sciences and Resources Institute

University of South Carolina

901 Sumter Street

4th Floor, Bymes Building

Columbia, SC 29208

803-777-0176

rtolton@esri.esri.sc.edu

Dr. Robert S. Turner

Director

NCEDR / ORNL

314 UT Conference Center

Knoxville, TN 37996-4138

423-974-4585

rsturner@utk.edu

Ms. Martha Walters

Environmental Projects Coordinator

San Francisco Development Agency

City of San Francisco, CA

770 Golden Gate Avenue

San Francisco, CA 94102

415-749-2474

Mr. Mitch West

Manager of Business Systems Development

Department of Environmental Quality

State of Oregon

811 Southwest 6th Avenue

Portland, OR 97204

503-229-6295

west.mitch@deq.state.or.us
Mr. Rick Taupier

Associate Director

Office of Geographic Information Analysis

University of Massachusetts at Amherst

Blaisdell House

Amherst, MA 01003

413-545-2842

taupier@tei.umass.edu

Dr. Bruce Tonn

Senior Researcher

Policy Analysis Systems Group

NCEDR / ORNL

Bethel Valley Road

Building 4500N, MS 6207

P.O. Box 2008

Oak Ridge, TN 37831-6207

423-574-4041

bet@ornl.gov

Mr. Brahm P. Verma

Professor

Biological and Agricultural Engineering

University of Georgia

Driftmier Engineering Center

Athens, GA 30602-4435

706-542-0870

bverma@bae.uga.edu

Mr. Tom Wanich

Information Management Consultant

Department of Environmental Protection

Commonwealth of Pennslyvania

400 Market Street

P.O. Box 2063

Harrisburg, PA 17105-2063

717-772-5911

wanich.tom@dep.state.pa.us

Mr. Jim Whitter

Senior Staff Assistant

Center For Best Practices

National Governors' Association

444 N. Capitol Street, Suite 267

Washington, DC 20001-1512

202-624-7825

jwhitter@nga.org 
Ms. Susan M. Willis

Deputy Division Director

Systems Integration \& Data Analysis

Department of Environmental Protection

Commonwealth of Massachusetts

One Winter Street

Boston, MA 02108

617-292-5572

sue.willis@state.ma.usa

Mr. Ron Woodburn

Agency Integration Specialist

Bureau of Information \& Telecommunications

State of South Dakota

523 East Capitol

Pierre, SD 57501

605-773-4750

ronw@denr.state.sd.us
Ms. Chantale Wong

Senior Advisor

U.S. Department of Interior

1849 C Street, NW

Room 6117

Washington, DC 20240

202-208-4203

chantale@cais.com

Ms. Irene Yarmak

Assistant Director

Strategic Computing and Telecommunications

Kennedy School of Government

Harvard University

79 JFK Street

Cambridge, MA 02138

617-495-3036

irene_yarmak@harvard.edu 
APPENDIX B. WORKSHOP AGENDA

INFORMATION TECHNOLOGY AND ENVIRONMENTAL DECISIONMAKING

Workshop Agenda

THURSDAY, OCTOBER 1

2:30 p.m. REGISTRATION (Taubman Building Rotunda)

3:00 p.m. Welcome and Introduction - Jerry Mechling and Tom Fletcher, KSG .

(Wiener Auditorium)

3:20 p.m. Case: "The Toxics Release Inventory: Sharing Government Information with the Public" - Jerry Mechling, $K S G$ (Wiener Auditorium)

4:45 p.m. Issues Overview - Jerry Mechling, KSG (Wiener Auditorium)

5:10 p.m. END, DAY ONE FORMAL AGENDA

5:30 p.m. BUS DEPARTS FOR THE JOHN F. KENNEDY PRESIDENTIAL LIBRARY AND MUSEUM COLUMBIA POINT

6:15 p.m. FILM AND TOUR OF LIBRARY

7:00 p.m. COCKTAILS AND DINNER

8:00 a.m. CONTINENTAL BREAKFAST (Taubman Building Rotunda)

8:30 a.m. An Introduction to Current Practice - Jerry Mechling, KSG (Wiener Auditorium)

8:45 a.m. Current Practice Session \#1

2 or 3 of the following will be offered during each session:

- Using GIS to Clean-up and Redevelop Brownfield Sites in New York City, Annette Barbaccia and Henry Colon, City of New York

- Envirofacts Data Warehouse, Jeff Byron, U.S. Environmental Protection Agency

- The Challenges of Scientific Information Management, Jeffrey Frithsen, U.S. Environmental Protection Agency

- Creating a Web-based Record of New Jersey Environmental Data, Linda Langschied and Ron Jantz, Rutgers University

- Chemical Scorecard Project, William Pease, Environmental Defense Fund

- Information Integration Project, Lynn Singleton, State of Washington

- An Analysis of Benefits from the Use of GIS for Environmental Planning, Rick Taupier, University of Massachusetts, Amherst 


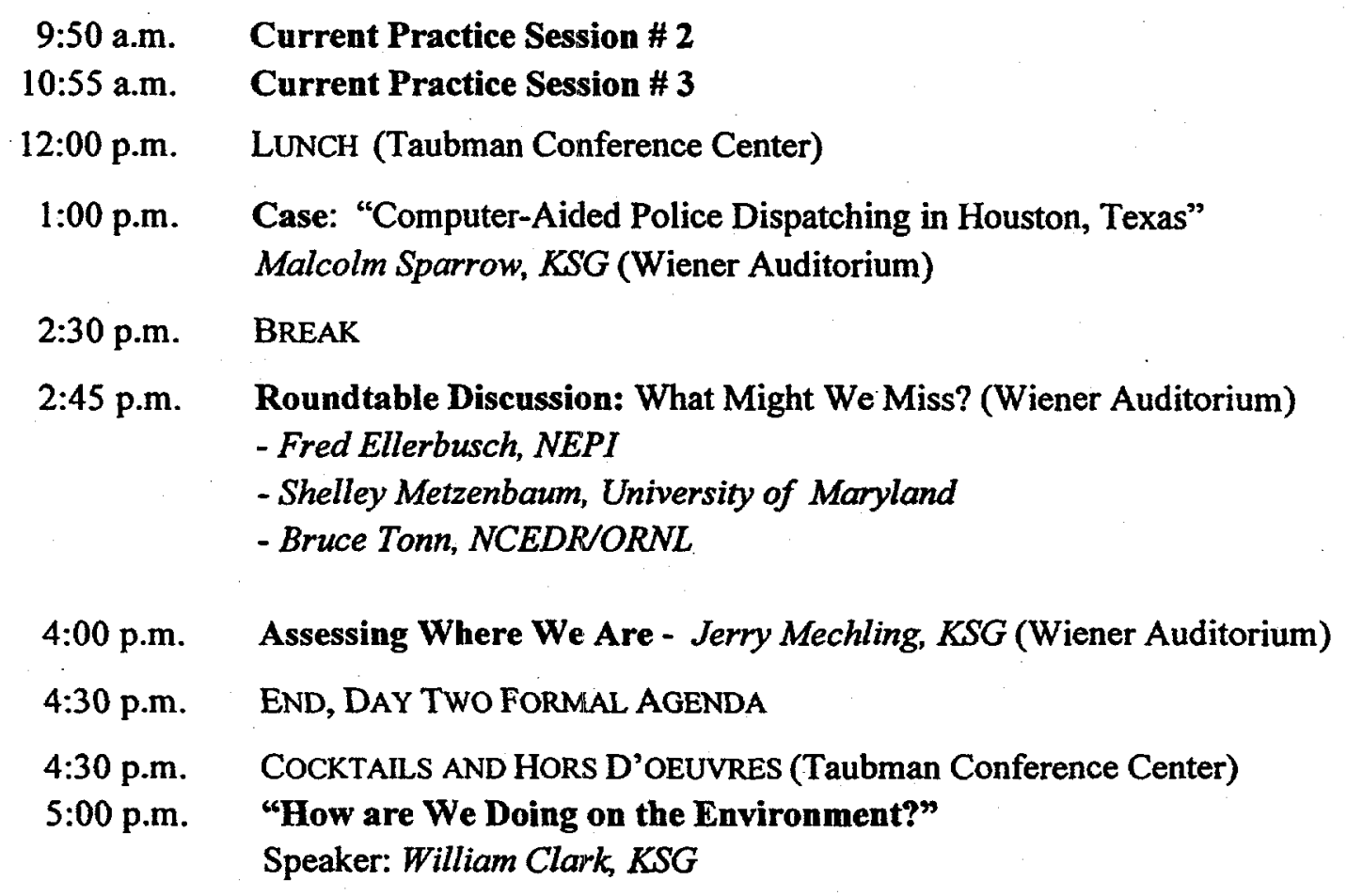

\section{SATURDAY, OCTOBER 3}

8:00 a.m. CONTINENTAL BREAKFAST (Taubman Rotunda)

8:30 a.m. Problem Discussion/Interactive Survey (Wiener Auditorium)

10:00 a.m. BREAK .

10:15 a.m. Roundtable Discussion: Where from Here? (Wiener Auditorium)

- Bill Hogan, KSG

- Tom Parris, Harvard University

- Rick Taupier, University of Massachusetts, Amherst

11:30 a.m. Pulling the Pieces Together - Jerry Mechling, KSG (Wiener Auditorium)

12:00 p.m. WORKSHOP CLOSE 


\section{INTERNAL DISTRIBUTION}

1. J. B. Cannon

2. G. E. Courville

3. T. R. Curlee

4. S. G. Hildebrand

5. R. Lee

6. C. I. Moser

7. R. B. Shelton
8. B. E. Tonn

9. R. Turner

10. Central Research Library

11. Document Reference Section

12. Laboratory Records

13. Laboratory Records - RC

\section{EXTERNAL DISTRIBUTION}

14. Dr. Lilia A. Abron, President, PEER Consultants, P.C., 1460 Gulf Blvd., $11^{\text {th }}$ Floor, Clearwater, FL 34630 .

15. Dr. Susan L. Cutter, Department of Geography, University of South Carolina, Columbia, SC 29208.

16. Dr. Thomas E. Drabek, Professor, Department of Sociology, University of Denver, Denver, CO 80208-0209.

17. Mr. P. Richard Rittelmann, FAIA, Executive Vice President, Burt Hill Kosar Rittelmann Associates, 400 Morgan Center, Butler, PA 16001-5977.

18. Dr. Susan F. Tierney, The Economic Resource Group, Inc., One Mifflin Place, Cambridge, MA 02138.

19. Dr. C. Michael Walton, Department of Civil Engineering, College of Engineering, The University of Texas at Austin, Cockrell Hall, Suite 4.2, Austin, TX 78712.

20. Office of Scientific and Technical Information, U.S. Department of Energy, P.O. Box 62, Oak Ridge, TN 37831. 